\title{
Evolution of the response of segregating populations of plums and the association with microsatellite markers of leaf scald
}

Marco Antonio Dalbó ${ }^{1}$, Gustavo Henrique Ferrerro Klabunde ${ }^{2}$, Rubens Onofre Nodari ${ }^{2}$, Denise Fernandes ${ }^{2}$ and Marcos Fernando Basso $^{3}$

Received 3 December 2009

Accepted 22 June 2010

\begin{abstract}
The evolution of leaf scald (Xylella fastidiosa) resistance was evaluated in individuals of seven plum segregating populations, consisted of seedling progenies originating from crosses involving nine plum cultivars, with varied levels of resistance. Plants were submitted to artificial inoculation in 2001 and evaluated annually from 2002 to 2007 for the evolution of leaf scald symptoms. All populations showed an evolution of symptom severity during the evaluated period. The population Amarelinha $x$ Carazinho was the most resistant while populations Chatardx Santa Rosa and Chatardx Simka were the most susceptible ones. The populations Chatard $x$ Harry Pickstone and Chatard $x$ Angeleno exhibited an intermediate behavior. The analysis of genetic segregation of microsatellite markers and disease resistance curves in different populations indicated that inheritance to leaf scald resistance is polygenic and predominantly recessive, with an eventual presence of major QTLs in susceptible parents.
\end{abstract}

Key words: Prunus salicina, late symptoms, inheritance of resistance.

\section{INTRODUCTION}

The Brazilian commercial production of plums is based on Japanese cultivars since they do not have a high chilling requirement and are able to withstand high temperatures in the summer (Ducroquet and Mondin 1997). While the term 'Japanese plum' was originally applied to the species Prunus salicina, the term 'European plum' is applied to cultivars that belong to the species Prunus domestica. However, most Japanese cultivars released for commercial purposes in the past few years involve a cross between $P$. salicina and several plum species of the same genus. Consequently, the term 'Japanese plum' is currently also applied to cultivars of this species and its interspecific hybrids (Okie and Hancock 2008).
The most important plum disease in Brazil is leaf scald, caused by the bacterium Xylella fastidiosa (Ducroquet et al. 2001). This bacterium infects the xylem vessels of plants and causes significant economic losses in several crops (Hopkins 1989), such as the leaf scald in plums (Raju et al. 1982), phony peach disease (Wells et al. 1987), pierce's disease of grapevine (Davis et al. 1978), leaf scorch in coffee (Hartung et al. 1994) and citrus variegated chlorosis (CVC) (Chang et al. 1993, Hartung et al. 1994), among others. Among the symptoms, X. fastidiosa causes the death of susceptible plants.

Particularly, leaf scald seriously attacked plum orchards in the State of Santa Catarina, causing the complete destruction of $90 \%$ of them during the period from 1975 to 1982 (Ducroquet and Mondin 1997). Although the disease

\footnotetext{
${ }^{1}$ Epagri, Estação Experimental de Videira, C.P. 21, 89.560-000, Videira, SC, Brazil

${ }^{2}$ Universidade Federal de Santa Catarina, C.P. 476, 88.040-900, Florianópolis, SC, Brazil. * E-mail: nodari@cca.ufsc.br.

${ }^{3}$ Embrapa Uva e Vinho, Centro Nacional de Pesquisa Uva e Vinho, Rua Livramento, 515, CP 130, 95.700-000, Bento Goncalves, RS, Brazil.
} 
is spread all over the State, it is less intense in cold areas (Ducroquet and Mondin 1997).

Xylella fastidiosa Wells et al. (1987) (Xanthomonadales: Xanthomonadaceae), a gram-negative and xylem limited bacterium, proliferates only in xylem vessels in roots, stems and leaves. The vessels are ultimately blocked by bacterial aggregates and by tyloses and gums formed by the plant. Other forms of occlusion occur after the host reactions such as the release of pectin and gums. Thus, the water and nutrients translocation is affected, which provokes water stress, membrane destruction and the obstruction of xylem vessels (Fry and Milholland 1990, Mollenhauer and Hopkins 1976). According to French and Katajima (1978), the chlorose and leaf scald symptoms in plum suggest the involvement of toxins.

The bacterium is efficiently acquired by vector insects, with no latent period, and persists in infective adult insects indefinitely (Severin 1949). Thus, this bacterium is primarily transmitted by insects, generally hymenopterans, such as sharpshooters. In coffee, where the average level of natural infectivity potential was $30.4 \%$, it is transmitted by xylem feeding insects and four sharpshooter species have been reported as vectors of $X$. fastidiosa (Yonce and Shang 1987).

Contaminated vegetative propagated materials such as cuttings, scion, and buddings also represent usual forms of contamination. However, contaminated matrix plants are the main source of inoculum. In addition, the high number of alternative hosts, including orchard plum weeds (ex: rye grass, macela, creeping signalgrass, Brazilian pusley, among others) helps the dissemination of X. fastidiosa because they are also sources of inoculum (Leite et al. 1997), since sharpshooters can bite unspecifically several species.

$X$. fastidiosa is rod-shaped with distinctive rippled cell walls, non-flagellate, does not form spores and measures 0.1-0.5 x 1-5 ìm, and strictly anaerobic (Wells et al. 1987). The genome sequence of the CVC strain of $X$. fastidiosa, clone 9a5c, was determined, and the nature of genes that were identified by annotation suggests a number of potential pathogenicity mechanisms, such as cell-wall hydrolysis, adhesion, intervessel migration, and toxicity (Simpson et al. 2000). Genetic diversity among the CVC strain of $X$. fastidiosa has also been detected (Lacava et al. 2001).

Since this bacterium can cause injury to distinct plant species, it was demonstrated that it is possible to differentiate strains of $X$. fastidiosa from different hosts with the use of AFLP markers (Kischi et al. 2008). This and other studies indicated that the infected strains in plums plants can be specifically identified.

In plums, it takes three or more years to manifest the disease symptoms in contaminated plants, which can be identified by apex drought, marginal necrosis, and leaf fall, delaying the growth and fruit ripening, reduction of plant development, and finally, causing plant death (Mohan et al. 1980). Affected trees yield increasingly fewer and smaller fruits until, after 3-5 years, they become economically worthless.

The first leaf scald symptoms can be observed in the old leaves and isolated branches. Later, the symptoms reach the entire plant (Leite et al. 1997). Initially, the symptoms appear as a light chlorosis in the apical and marginal areas of the leaf. Subsequently, the chlorosis enhances and migrates to the remainder part of the leaf. Then, the affected areas become necrotic and dry. The necrotic areas are covered by decomposing fungi and the regions between the necrotic and non affected areas still remains chlorotic (Mohan et al. 1980). In contaminated plants, the leaf and branches fall is accentuated form the branch top to the basis.

There is no chemical control. Thus, the prevention principles are recommended as the best approach to control the disease. This includes the use of disease free stocks, periodic inspections, resistant cultivars, eradication of contaminated materials, avoidance of new orchard establishment nearby contaminated ones, biological control of vectors (insects) and alternative hosts (Andrade 1995).

Most plum cultivars recommended for the State of Santa Catarina are susceptible to this disease. In addition, since the disease is transmitted by sharpshooters and there are many $X$. fastidiosa alternative hosts, the inoculum's dissemination is practically unavoidable (Ducroquet et al. 2001).

Thus, the main challenge of plum breeding programs in Brazil is to obtain cultivars that are resistant or tolerant to leaf scald. However, breeders are facing difficulties to develop new resistant or tolerant cultivars because the genetic basis of the resistance reaction to this disease is not known and a long period of time after the inoculation is required to show typical symptoms.

The appearance of the symptoms many years after the inoculation become a big problem for genetic improvement, since breeders have to wait over three years or more to evaluate and select resistant genotypes. 
Because it takes so long, the costs for breeding also increases. This situation is a good opportunity for the development of techniques allowing genotypic selection at seedling stage, which would save time and costs compared to phenotypic selection (Vieira et al. 2005).

In this situation, molecular markers are a powerful tool to find genomic regions associated to resistance and to provide a better understanding of genetic inheritance of this trait. Studies done on plums are very limited (Vieira et al. 2005) but previous works done to other species of Prunus can serve as a base. Microsatellite markers are especially useful because they usually can be amplified over a series of relative species. For genetic mapping purposes Aranzana et al. (2003) presented a genome-wide coverage genetic map of Prunus based on a series of microsatellite markers evenly spaced as anchors for each of the eight linkage groups. Other genetic maps generated from related species (Joobeur et al. 2000, Dierlewanger et al. 2004) can also be used as a reference for plum mapping projects. Dondini et al. (2006) made a comparison of SSR-based maps created for different Prunus species. A substantial co-linearity and sinteny was observed indicating that large genomic rearrangements in Prunus are not expected to be found.

Later breeding works are giving new insights for further research strategies to face this disease. Ledbetter et al. (2009) verified the winter curing of the almond leaf scorch disease caused by X. fastidiosa in Prunus dulcis, Prunus webbi, and the intra-specifics hybrids between these two species. The winter curing was obtained in plants inoculated with $X$. fastidiosa and grown outside of greenhouses during the winter time to accumulate chill hours (more than 1000). As a result, the authors detected a dramatic decrease in the frequency of plants with the typical symptoms and the presence of Xfastidiosa as well, in the following two seasons. Another work done by Ledbetter and Rogers (2009) found resistance hybrids between almond and peaches, whereas the parental population of almonds utilized in the cross was suceptible to $X$ fastidiosa. This finding would encourage additional strategies to be taken in the breeding programs in Southern Brazil.

This work reports the analysis of progenies originating from seven crosses between resistant or tolerant and susceptible cultivars of the Japanese plum submitted to artificial inoculation. The objective was to evaluate the reaction of segregating populations to the $X$. fatidiosa, the evolution of disease symptoms and resistance levels, and to associate it to molecular data in order to have a better understanding of the inheritance of the resistance to this disease.

\section{MATERIAL AND METHODS}

\section{Plant material}

The nine japanese plum cultivars utilized in the crosses exhibit different degrees of resistance or susceptibility to leaf scald (Table 1). Santa Rosa, Simka, Angeleno, Harry Pickstone and Leticia are traditional plum cultivars. Leticia is the name used in Brazil for the South African cultivar Laetitia. Chatard and Piamontesa are leaf scald resistant clones identified in Argentina. Carazinho and Amarelinha are local selections collected in southern Brazil, with an unknown origin. The segregating populations (Table 1) were developed at Epagri - Videira Experimental Station (Videira, SC, Brazil), located at lat $27^{\circ} 00^{\prime} 30^{\prime \prime} \mathrm{S}$, long $51^{\circ} 09^{\prime}$ 06" W and alt around $800 \mathrm{~m}$ asl.

\section{Management of the segregating populations}

The seedlings were planted in the field on own-roots. The distance among plants was $1 \mathrm{~m}$ and $5 \mathrm{~m}$ among lines. All management recommendations for commercial production were applied to the segregating populations, including the green and winter pruning. To control the fruit-flies (Anastrepha fraterculus, Ceratitis capitata) and grafolita (Grapholita molesta) the chemical products methidation and dimetoato were utilized. In addition, to control diseases caused by fungi, two or three sprays of Folicur $^{\circledR}$ (tebuconazole) were applied after harvesting, in order to avoid premature leaf fall caused by leaf diseases (rust, shot hole, among others), and to allow a better visualization of the leaf scald symptoms at the end of the cycle. Although Videira is considered an endemic region, all plants of the segregating populations were inoculated with Xylella fastidiosa in 2001, by grafting seedlings with vegetative material obtained from infested plants.

\section{Evaluation}

The evaluations of plant reaction to leaf scald began in 2002, always in February and March of each year. Five populations were evaluated since 2002, one in 2003 and the other two in 2004 (Table 1). The inoculated plants were classified in distinct classes of reactions according to the symptoms, based on the scale developed by Ducroquet et al. (2001): 0) absence of symptoms; 1) leaves with symptoms on few branches; 2) leaf symptoms spread 
Table 1. Parental of crosses, year of transplant, number of plants per segregating population, year of evaluations and disease severity of the different segregating populations

\begin{tabular}{|c|c|c|c|c|c|c|c|}
\hline Population & Female* & Male* & $\begin{array}{l}\text { Year of } \\
\text { the } \\
\text { transplant }\end{array}$ & $\begin{array}{l}\text { Number } \\
\text { of plants }\end{array}$ & $\begin{array}{l}\text { Year of the } \\
\text { first } \\
\text { evaluation }\end{array}$ & $\begin{array}{c}\text { Number of } \\
\text { evaluated } \\
\text { years }\end{array}$ & $\begin{array}{l}\text { Average severity } \\
\text { of the disease in } \\
\text { the last year of } \\
\text { evaluation }\end{array}$ \\
\hline 1 & Chatard (1) & Harry Pickstone (4) & 1993 & 60 & 2002 & 5 & 3.4 \\
\hline 2 & Chatard (1) & Simka (5) & 1993 & 42 & 2002 & 4 & 4.1 \\
\hline 3 & Chatard (1) & Angeleno (4) & 1994 & 44 & 2002 & 5 & 2.7 \\
\hline 4 & Chatard (1) & Santa Rosa (5) & 1994 & 175 & 2002 & 5 & 4.7 \\
\hline 5 & Chatard (1) & Amarelinha (2) & 1995 & 51 & 2002 & 4 & 2.6 \\
\hline 6 & Amarelinha (2) & Carazinho (0) & 1998 & 259 & 2004 & 4 & 1.2 \\
\hline 7 & Piamontesa (1) & Letícia (3) & 1998 & 103 & 2004 & 4 & 2.9 \\
\hline
\end{tabular}

The values $0,1,2,3,4$, and 5 among parenthesis are scores of the reactions from parental plants correspond to the following phenotypic classes Highly Resistant, Resistant, Moderately Resistant, Moderately Susceptible, Susceptible, and Highly susceptible, respectively.

around $50 \%$ of the branches; 3 ) symptoms on leaves of all branches; 4) dryness in $50 \%$ of the plant branches; and 5) dryness in more than $50 \%$ of the branches, and plant weakening or dead. The data were submitted to the descriptive statistics.

\section{Molecular markers}

A series of 60 microsatellite markers were used to find possible genomic regions associated to leaf scald resistance in two segregant populations (Chatard x Harry Pickstone and Chatard x Angeleno). The microsatellite loci are regularly dispersed in the genome and were selected based on previous genetic mapping works done on Prunus species (Aranzana et al. 2003, Dondini et al. 2006) and because they showed good PCR amplification in our laboratory.

The two populations were chosen because the clear segregation for their leaf scald resistance observed in their progenies. After many years of disease evolution, the two populations presented a segregation curve with a balanced proportion of susceptible and resistant seedlings (Figure 1). The five more resistant and five more susceptible individuals from each population were selected and DNA samples of these individuals, together with parental, were used in the initial screening of microsatellite markers. When an allele was more frequent in one group compared to the other (resistant or susceptible) the microsatellite marker was analyzed in all individuals of the population.

DNA extraction was done with a modified method of Doyle and Doyle (1987), as described in Vieira et al. (2005). The PCR reactions were conducted as follows: $4 \mathrm{~min}$ at 94 ${ }^{\circ} \mathrm{C}, 35$ cycles of $45 \mathrm{~s}$ each $94{ }^{\circ} \mathrm{C}, 1 \mathrm{~min}$ at a variable temperature $\left(52-57^{\circ} \mathrm{C}\right)$ as optimized for each pair of primers $)$,
$1 \mathrm{~min}$ at $72^{\circ} \mathrm{C}$, followed by $7 \mathrm{~min}$ at $72^{\circ} \mathrm{C}$ for final extension. PCR products were separated by electrophoreses in $6 \%$ polyacrilamide gel, and visualized by silver staining, as previously described (Creste et al. 2001).

\section{RESULTS AND DISCUSSION}

The analysis of the frequency distribution per class of reaction to the $X$. fastidiosa from 2002 to 2007 revealed the evolution of the severity of the symptoms in all studied populations (Figure 1). The seven populations presented distinct disease severity averages in the last evaluation (Table 1) but all had a tendency of increasing frequency of more susceptible classes over the years. Although sometimes a decrease in disease severity in one year was observed, afterwards it increased again. As expected, the score value in the last evaluation was the highest in the analyzed period (Figure 1). Previously, Ducroquet et al. (2001) concluded that with inoculation, the severity of the symptoms of leaf scald increases with the plant age in segregating populations.

It also has to be considered that the severity of this disease is dependent on climatic conditions, mainly temperature. Videira has an annual average of 500 hours below $7{ }^{\circ} \mathrm{C}$. It was observed that in other locations of the State of Santa Catarina with similar latitudes but higher elevation areas (above 1,200 m) the incidence of leaf scald is virtually absent. On the other hand, in warmer areas near the coast, leaf scald symptoms are more intense and evolve faster. Thus, the results presented here are representative of this region and it was obtained in relatively mild conditions for the development of Xylella fastidiosa. However, even in these conditions this disease causes plant death in a few years in the case of very 

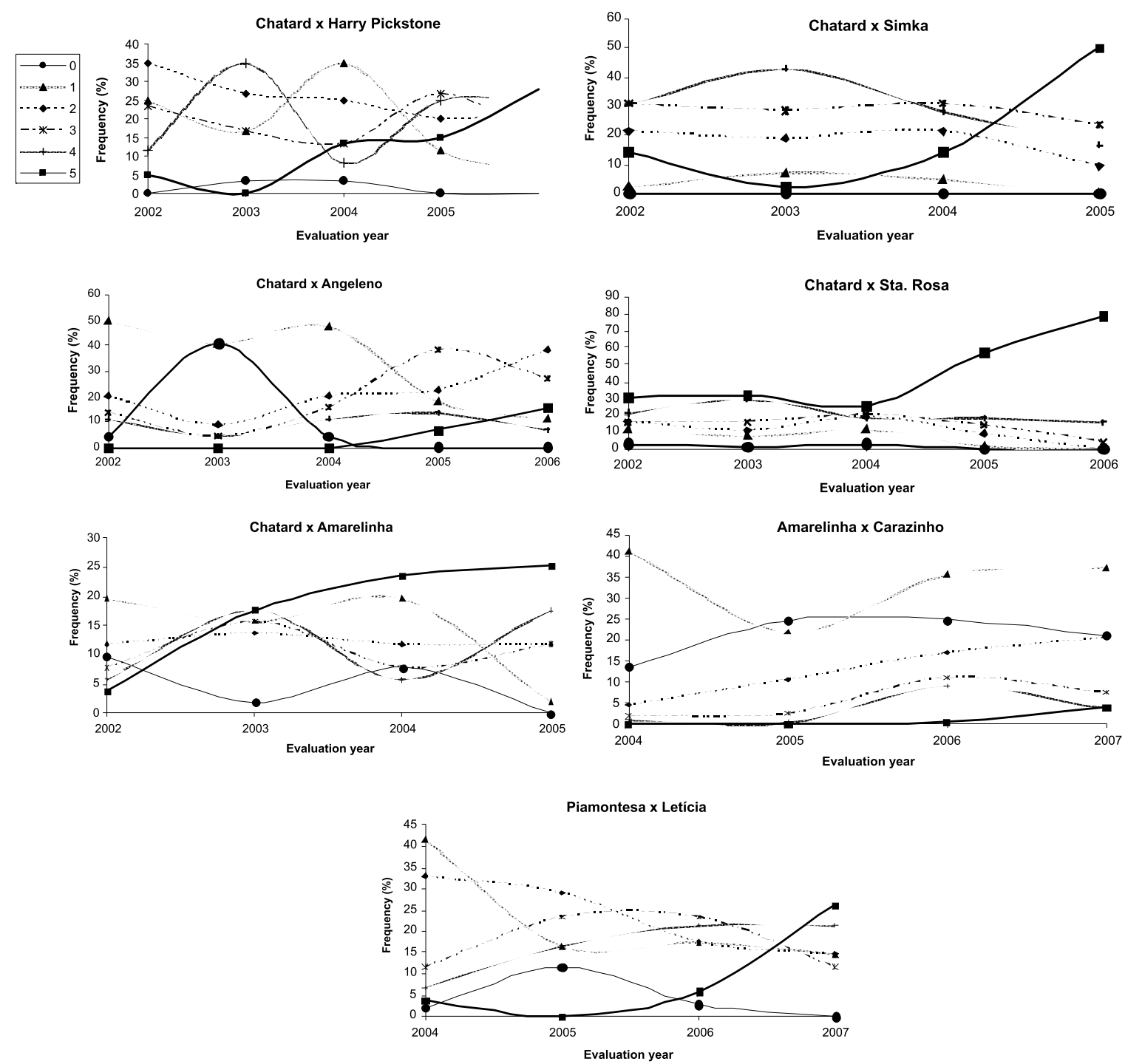

Figure 1. Evolution of the symptoms of leaf scald in seven segregating populations of japanese plums caused by Xylella fastidiosa, over a six years of evaluation.

susceptible cultivars, such as Santa Rosa and Simka, and the same happened to many seedlings of progenies studied here.

Several factors can affect expressions of this disease, such as the age of the plants, and the natural inoculation of $X$. fastidiosa done by sharpshooters previously to artificial inoculation. All of them can increases the appearance of the symptoms. However, even considering these sources of variability, the degree of susceptibility of parental, especially the most susceptible one, looks to be a very important factor associated to average severity of the disease (Table 1).
The frequencies of scores 0 and 5 on the leaf scald scale were similar among most of the distinct segregating populations (Figure 2 and 3 ). In six out of seven segregating populations the frequency of the score 0 in the last year of evaluation was zero. On the other hand, the frequency of the score 5 of the last evaluation was the highest compared to score 5 in previous evaluations, varying from $25.4 \%$ in the segregating population Chatard $\mathrm{x}$ Amarelinha to $78.8 \%$ in the population Chatard x Sta. Rosa (Figure 3).

The segregating population showing the highest level of resistance to the leaf scald and plants showing score 0 in the last evaluation was Amarelinha x Carazinho. 


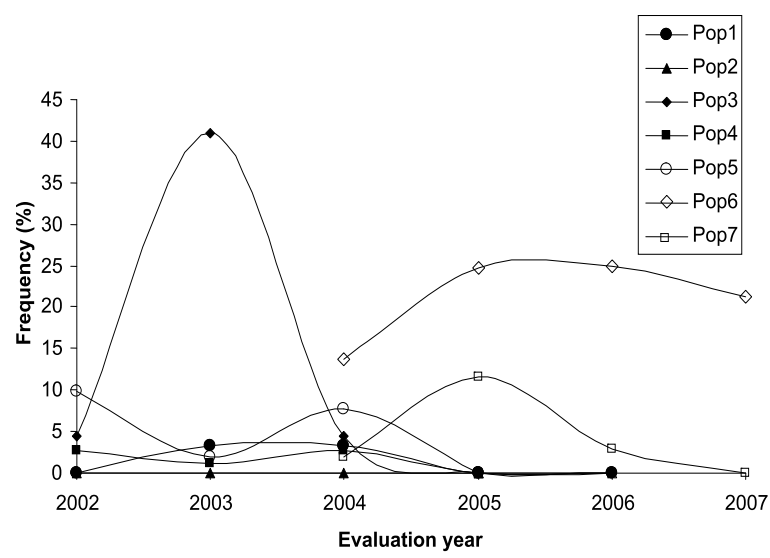

Figure 2. F requency (\%) of plants with a score 0 (highly resistant) over six years of evaluation. See Table 1 for the parental of the seven crosses.

In addition, the score 5 of this population in the last evaluation was $4.2 \%$, a value inferior to others. The cultivar Carazinho is highly resistant and Amarelinha is moderately resistant (Figure 2, Table 1).

The most susceptible populations were Chatard $\mathrm{x}$ Simka (pop. 2) and Chatard x Santa Rosa (pop 4), showing in the last year a severity index of 4.1 and 4.7 , respectively (Table 1). Simka and Santa Rosa are commercial but highly susceptible varieties. On the other hand, Chatard produces low quality fruits but it is considered resistant (Table 1). The progenies of these two populations, even though it descends from one resistant parental (Chatard), showed a high degree of susceptibility, on average. Resistant individuals were present but in a very small percentage.

The populations Chatard x Harry Pickstone and Chatard $\mathrm{x}$ Angeleno exhibited an intermediate behavior, with a balanced distribution of resistant and susceptible individuals at the end of the evaluation period. This kind of distribution in relatively small progenies (65 and 56 individuals, respectively) suggests the presence of major genes, although the inheritance to leaf scald has a clear quantitative character. By this reason, these two populations were characterized with microsatellite markers to detect possible genomic regions responsible for an expressive percentage of phenotypic variation of the leaf scald resistance and a better understanding of the inheritance of this trait. The small number of individuals is a limitation for genetic mapping, so the option was to do an exploratory work with microsatellite markers regularly spaced in the genome, according to previous works on Prunus species (Aranzana et al. 2001, Dondini et al. 2006).

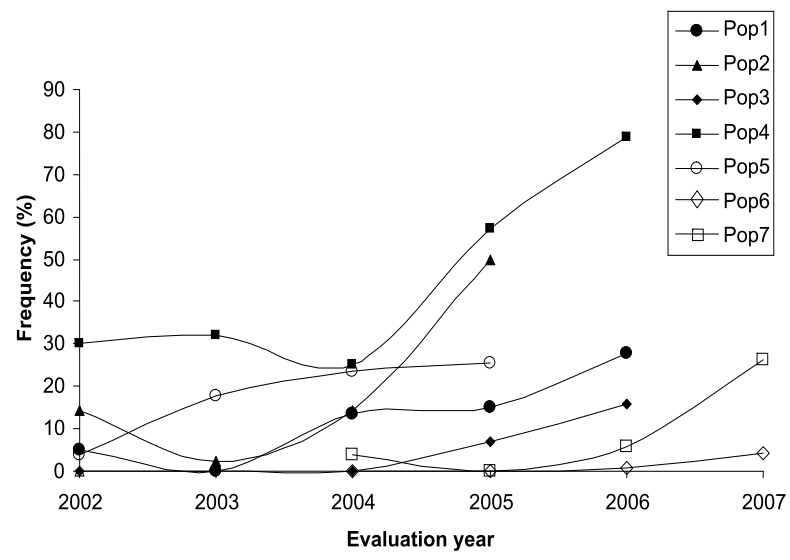

Figure 3. Frequency (\%) of plants with score 5 (highly susceptible) over six years of evaluation. See Table 1 for the parental of the seven crosses.

Sixty microsatellite loci were tested, being 25 polymorphic in Chatard, 27 in Harry Pickstone and 25 in Angeleno. Leaf scald resistance was significantly associated to the segregation of locus CPDCT16 in Harry Pickstone $\left(\mathrm{R}^{2}=0.187 ; \mathrm{P}<0.0006\right)$ and locus UPD 98-405 in Angeleno $\left(\mathrm{R}^{2}=0.168 ; \mathrm{P}<0.0062\right)$. In the general map of Prunus (Aranzana et al. 2003), these loci are located in different regions of the genome. The CPDCT16 locus was mapped in linkage group 5 and the UDP 98-405 locus in group 7. The real contribution of each region could not be estimated because the markers were well spaced and there were no saturation with other markers in order to have a more precise location of the QTLs. It is also possible that other minor QTLs were not detected due to low marker saturation and a small number of individuals in the progenies.

The previous genetic mapping works on other Prunus species resulted in maps with a total genetic distance around $1000 \mathrm{cM}$ (Dondini et al. 2006). If we consider this distance as expected also for plums, on average one polymorphic locus for $35 \mathrm{cM}$ was tested. It cannot be consider an accurate QTL analysis but it is enough for the identification of major QTLs, which are expected in the present case and are the ones with practical uses for breeding purposes.

No significant association between leaf scald resistance and marker segregation in the cultivar Chatard, the resistant cultivar, was found. In this case, a probable reason is that differences observed in the progeny were mostly due to QTL segregation in the more susceptible parental, indicating that alleles for susceptibility are dominant over the ones conditioning resistance. 
Population 4, originated from the cross Chatard $\mathrm{x}$ Santa Rosa, had already submitted to QTL analysis for leaf scald resistance, based on genetic maps constructed with a high number of molecular markers (Vieira et al. 2005). In this cross, no major QTLs in Chatard were identified, reinforcing the hypothesis of no segregation of major genes or QTLs in this cultivar and that this source of resistance is in a homozygote recessive form. In addition, no major QTLs in Santa Rosa were found, which can be due to the tendency of individuals in the progeny being concentrated in low resistance classes.

One of the main features observed in crosses between Chatard with Santa Rosa and Simka, is the absence of resistant individuals at the end of the evaluation period (Figure 1). At least in these two cases, when one parental is highly susceptible there are no individuals in the progeny with high levels of resistance, even if the other parental is resistant, which is another evidence of the dominant nature of susceptibility. The presence of resistant individuals was expressive only in crosses without a highly susceptible parental involved (Figure 1).

The analysis of distribution curves per classes of leaf scald susceptibility in the different progenies indicated a typical polygenic inheritance of this trait but with a tendency of resistance being predominantly recessive. However, molecular marker analysis suggests that an important part of inheritance is controlled by some specific regions of the genome that segregated only in the more susceptible parents.

These results have important consequences for breeding purposes. The recessive nature of the QTLs found does not encourage the use of marker-assisted selection, at least for the cultivar Chatard as the source of resistance. On the other hand, the recessive inheritance of leaf scald resistance helps in the long term phenotypic selection, since selection against dominant alleles is easier, although it takes a long time to have a consisted field evaluation. However, this study was largely based on the cultivar Chatard as the resistance source and other studies are necessary to evaluate the potential of other resistant genotypes.

Future work on plum breeding to achieve resistance to leaf scald should include a more deep molecular approach, such as those utilized by Ledbetter et al. (2009), by monitoring not only symptoms, but the specific genome of $X$. fastidiosa as well, since the authors found distinct genomes infecting almond and peaches. Thus, it may be possible that specific primers can be designed to find the specific plum strains.

\section{ACKNOWLEDGEMENTS}

The authors would like to thank EMBRAPA/ PRODETAB for the financial support of this work and CNPq for the scholarship to GHFK and RON.

\title{
E volução da resposta de populações segregantes de ameiexeira e associação com marcadores microssatélites à escaldadura das folhas
}

\begin{abstract}
RESUMO - Avaliou-se o nível de resistência de sete populações segregantes de ameixeira à escaldadura das folhas (Xylella fastidiosa), criadas com a utilização de nove cultivares apresentando variados níveis de resistência à doença. As populações foram submetidas à inoculação artificial e avaliadas anualmente a partir de 2002 quanto a evolução dos sintomas da escaldadura. A população segregante Amarelinha x Carazinho se mostrou a mais resistente, enquanto as populações Chatard $x$ Santa Rosa e Chatard x Simka apresentaram maior susceptibilidade à escaldadura das folhas. A co-segregação foi avaliada com auxílio dos marcadores microssatélites, nas populações Chatard x Harry Pickstone e Chatard x Angeleno, por apresentarem comportamento intermediário em relação à doença. A análise da segregação genética dos 60 marcadores microssatélites e das curvas de resistência à doença em diferentes populações, indicam que a herança da resistência à escaldadura das folhas é poligênica e predominantemente recessiva, com a eventual presença de QTLs no parental suscetível.
\end{abstract}

Palavras-chave: Prunus salicina, sintomas tardios, herança da resistência. 


\section{REFERENCES}

Andrade ER (1995) Doenças do pessegueiro e da ameixeira e seu controle em Santa Catarina. EPAGRI, Florianópolis, 52p. (Boletim Técnico, 71)

Aranzana MJ, Pineda A, Cosson P, Dierlewanger E, Ascasiber J, Cipriano G, Ryder CD, Testolin R, Abbott A, King GJ, Iezzoni AF and Arus P (2003) A set of simple-sequence repeat (SSR) markers covering the Prunus Genome. Theoretical and Applied Genetics 108: 819-825.

Chang CJ, Garnier M, Zreik L, Rossetti V and Bove JM (1993) Culture and serological detection of xylem-limited bacterium causing citrus variegated chlorosis and its identification as a strain of Xylella fastidiosa. Current Microbiology 27: 137-142.

Creste S, Tulmann-Neto A and Figueira A (2001) Detection of single sequence repeat polymorphisms in denaturing polyacrylamide gels by silver staining. Plant Molecular Biology Reporter 19: 1-8.

Davis MJ, Purcell AH and Thomson SV (1978) Pierce's disease of grapevines: isolation of the causal bacterium. Science 199: $75-77$.

Dierlewanger E, Cosson P, Howad W, Capdeville G, Bosselut N, Claverie M, Voisin R, Poizat C, Lafargue B, Baron O, Laigret F, Kleinhentz M, Arús P and Esmejaud D (2004) Microssatelite genetic linkage maps of mirobalan plum and almond-peach hybrid - location of root-knot nematode resistance genes. Theoretical and Applied Genetics 109: 827-838.

Dondini L, Lain O, Geuna F, Banfi R, Gaiotti F, Tartarini S, Bassi $\mathrm{D}$ and Testolin R (2006) Development of a new SSR-based linkage map in apricot and analysis of sinteny with existing Prunus maps. Tree Genetics and Genome 3: 239-249.

Doyle JJ and Doyle JL (1987) Isolation of plant DNA from fresh tissue. Focus 12: 13-15.

Ducroquet JPHJ, Andrade ER de and Hickel ER (2001) A escaldadura das folhas da ameixeira em Santa Catarina. EPAGRI, Florianópolis, 55p. (Boletim Técnico, 118)

Ducroquet JPHJ and Mondin VP (1997) Cadeias produtivas do estado de Santa Catarina: pêssego e ameixa. EPAGRI, Florianópolis, 80p. (Boletim Técnico, 80)

French W and Katajima EW (1978) Ocurrence of plum leaf scald in Brazil and Paraguay. Plant Disease Reporter 62: 1035-1038.

Fry SM and Milholland RD (1990) Multiplication and translocation of Xylella fastidiosa in petioles and stems of grapevines resistant, tolerant and susceptible to Pierce's disease. Phytopathology 80: $61-65$.

Hartung JS, Beretta J, Brlanski RH, Spisso J and Lee RF (1994) Citrus variegates chlorosis bacterium: axenic culture pathogenicity and serological relationschips with other strains of Xylella fastidiosa. Phytopathology 84: 591-597.

Hopkins DL (1989) Xylella fastidiosa: xylem-limited bacterial pathogen of plants. Annual Reviews of Phytopathology 27: 271-290.
Joobeur T, Periam N, de Vicente MV, King GJ and Arus P (2000) Development of a second generation linkage map for almond using RAPD and SSR markers. Genome 43: 649-655.

Kishi LT, Wickert E and Lemos EGM (2008) Evaluation of Xylella fastidiosa genetic diversity by fAFPL markers. Revista Brasileira de Fruticultura 30: 202-208.

Lacava PT, Araújo WL, Maccheroni W and Azevedo JL (2001) RAPD profile and antibiotic susceptibility of Xylella fastidiosa causal agent of citrus variegated chlorosis. Letters in Applied Microbiology 33: 302-306.

Ledbetter CA, Chen J, Livingston S and Groves RL (2009) Winter curing of Prunus dulcis cv 'Butte' $P$. webbii and their interespecific hybrid in response to Xylella fastidiosa infections. Euphytica 169: 113-122.

Ledbetter CA and Rogers EE (2009) Differential susceptibility of prunus germplasm (subgenus Amygdalus) to a California isolate of Xylella fastidiosa. HortScience 44: 1928-1931.

Leite RM, Leite Junior RP and Ceresini PC (1997) Hospedeiros alternativos de Xylella fastidiosa entre plantas invasoras de pomares de ameixeira com escaldadura da folha. Fitopatologia Brasileira 22: 54-57.

Mohan SK, Leite Junior RP, Tsuneta M and Hauagge R (1980) Problema de escaldadura das folhas no estado do Paraná. IAPAR, Londrina, 70p. (Informe de Pesquisa, 31).

Mollenhauer HH and Hopkins DL (1976) Xylem morphology of Pierce's disease-infected grapevines with different levels of tolerance. Physiology Plant Pathology 9: 95-100.

Okie WR and Hancock JF (2008) Plums. In Hancock JF (ed.) Temperate fruit crop breeding. Springer Science Business Media, New York, p.337-357.

Raju BC, Wells JM, Nyland G, Brlansky RH and Lowe SK (1982) Plum leaf scald: isolation. culture and pathogenicity of the causal agent. Phytopathology 72: 1460-1466.

Severin HHP (1949) Transmission of the virus of Pierce's disease by leafhoppers. Hilgardia 19: 190-202.

Simpson AJG, Reinach FC and Arruda P (2000) The genome sequence of the plant pathogen Xylella fastidiosa. Nature 406: 151-157.

Vieira EA, Nodari RO, Dantas ACM, Dalbó, M, Ducroquet JPHJ and Vanz CB (2005) Genetic mapping of the japanese plum (Prunus sp.) Crop Breeding and Applied Biotechnology 5: 29-37.

Yonce CE and Shang CJ (1987) Detection of Xylella-limited bacteria from sharpshooter leafhoppers and their feeding hosts in peach environs monitored by culture isolations and ELISA techniques. Environmental Entomology 16: 68-71.

Wells JM, Raju BC, Huang HY, Weisburg WG, Mandelco PL and Brenner DJ (1987) Xylella fastidiosa gen. nov.; gram negative, xylem limited fastidious plant bacteria related to Xanthomonas spp. International Journal Systematic Bacteriology 37:130-143. 